
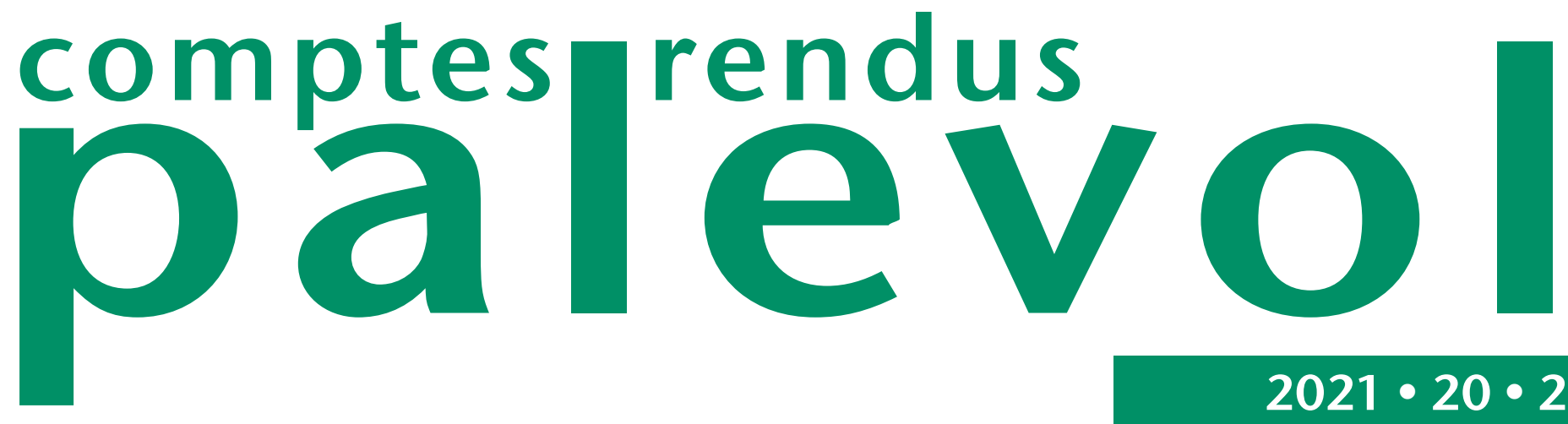

$2021 \cdot 20 \cdot 2$

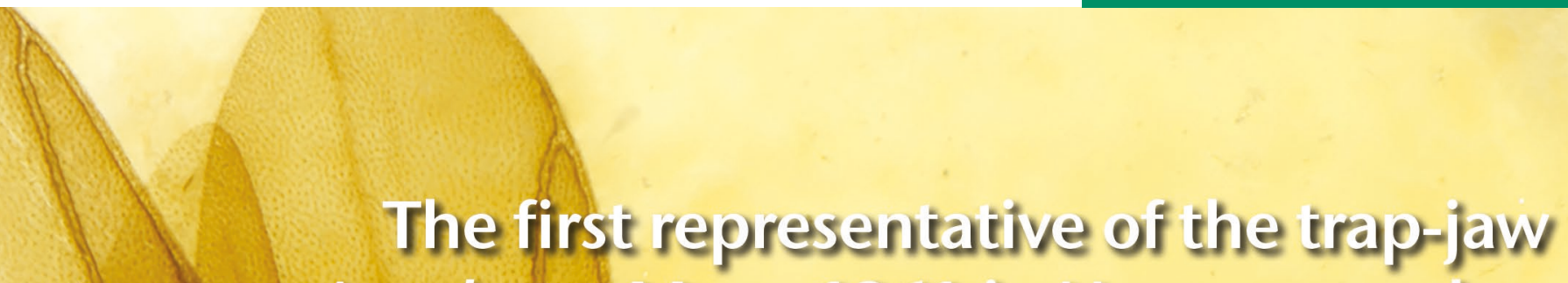
ant genus Anochietus Mbays, J86'] ins Neogene ambers

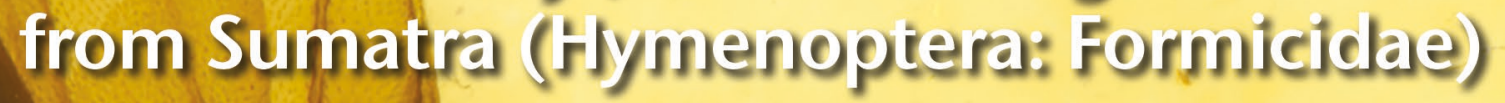

Valerie NGO MULLER, Romain GARROUSIE, Thomas SCFUBNEL, Jean-Viare POUILLON, VIgO CHRISTOPHERSEN, Alme CFRISTOPFIERSEN \& Andre NEL

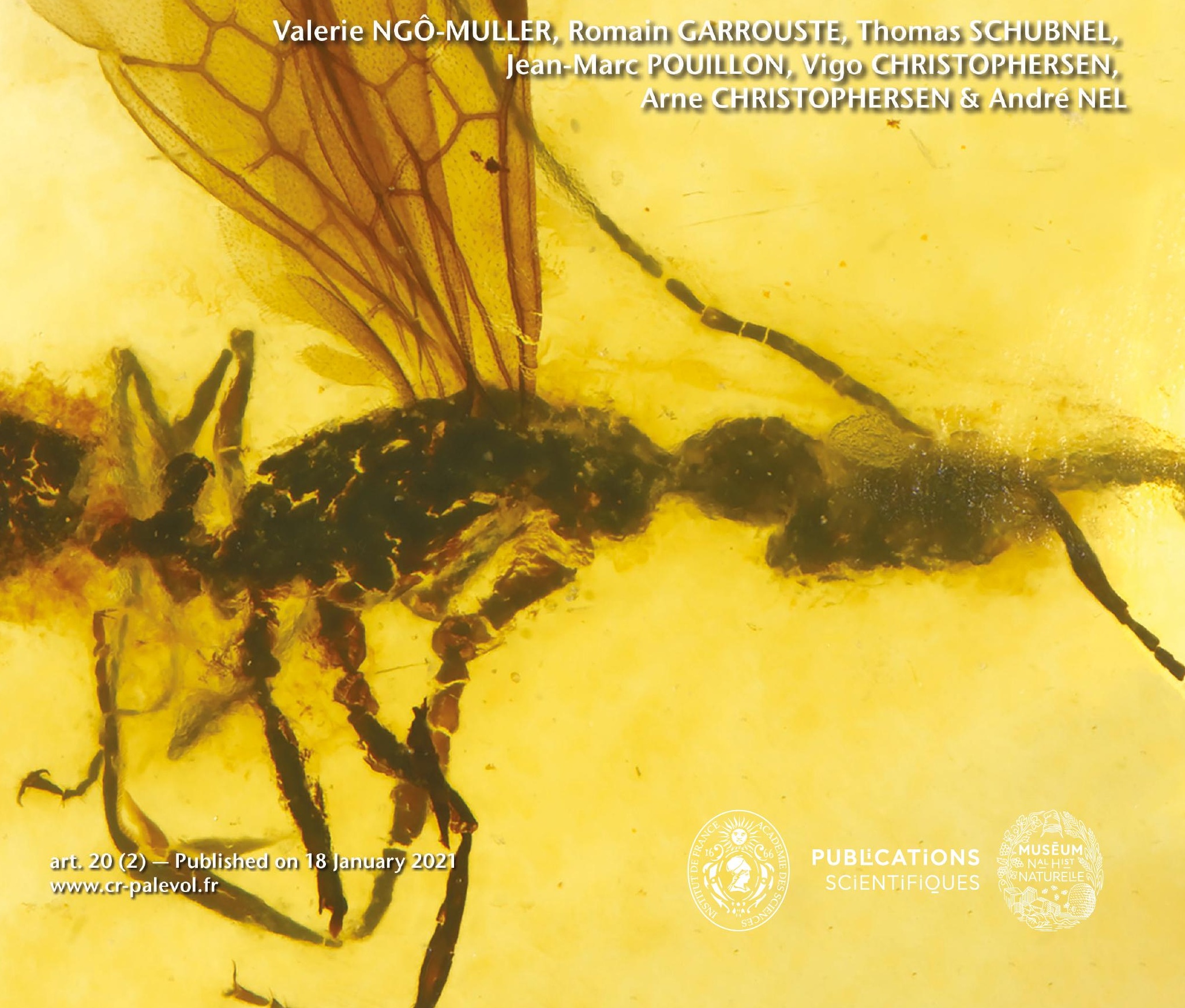


DiRECTEURS DE LA PUBLICATION / PUBLICATION DIRECTORS:

Bruno David, Président du Muséum national d'Histoire naturelle

Étienne Ghys, Secrétaire perpétuel de l'Académie des sciences

RÉDACTEURS EN CHEF / EDITORS-IN-CHIEF: Michel Laurin (CNRS), Philippe Taquet (Académie des sciences)

AssistANTE DE RÉDACTION / AsSISTANT EDITOR: Adeline Lopes (Académie des sciences ; cr-palevol@academie-sciences.fr)

Mise EN PAGE / PAGE LAYOUt: Fariza Sissi, Audrina Neveu (Muséum national d'Histoire naturelle; fariza.sissi@mnhn.fr)

ÉDITEURS ASSOCIÉS / ASSOCIATE EDITORS ( ${ }^{*}$, took charge of the editorial process of the article/a pris en charge le suivi éditorial de l'article):

Amniotes du Mésozoïque/Mesozoic amniotes

Hans-Dieter Sues (Smithsonian National Museum of Natural History, Washington)

Lépidosauromorphes/Lepidosauromorphs

Hussam Zaher (Universidade de São Paulo)

Métazoaires/Metazoa

Annalisa Ferretti* (Università di Modena e Reggio Emilia, Modena)

Micropaléontologie/Micropalaeontology

Maria Rose Petrizzo (Université de Milan)

Palaeoanthropology

R. Macchiarelli (Université de Poitiers, Poitiers)

Paléobotanique/Palaeobotany

Evelyn Kustatscher (The Museum of Nature South Tyrol, Bozen/Bolzano)

Paléoichthyologie/Palaeoichthyology

Philippe Janvier (Muséum national d'Histoire naturelle, Académie des sciences, Paris)

Palaeomammalogy (small mammals)

L. van den Hoek Ostende (Naturalis Biodiversity Center, CR Leiden)

Palaeomammalogy (large and mid-sized mammals)

L. Rook (Università degli Studi di Firenze, Firenze)

Prehistorical archaeology

M. Otte (Université de Liège, Liège)

Tortues/Turtles

Juliana Sterli (CONICET, Museo Paleontológico Egidio Feruglio, Trelew, Argentine)

COUVERTURE / COVER:

Made from the Figures of the article.

Comptes Rendus Palevol est indexé dans / Comptes Rendus Palevol is indexed by:

- Cambridge Scientific Abstracts

- Current Contents $®$ Physical

- Chemical, and Earth Sciences ${ }^{\circledR}$

- ISI Alerting Services ${ }^{\circledR}$

- Geoabstracts, Geobase, Georef, Inspec, Pascal

- Science Citation Index ${ }^{\circledR}$, Science Citation Index Expanded ${ }^{\circledR}$

- Scopus ${ }^{\circledR}$

Les articles ainsi que les nouveautés nomenclaturales publiés dans Comptes Rendus Palevol sont référencés par / Articles and nomenclatural novelties published in Comptes Rendus Palevol are registered on:

- ZooBank ${ }^{\circledR}$ (http://zoobank.org)

Comptes Rendus Palevol est une revue en flux continu publiée par les Publications scientifiques du Muséum, Paris et l'Académie des sciences, Paris Comptes Rendus Palevol is a fast track journal published by the Museum Science Press, Paris and the Académie des sciences, Paris

Les Publications scientifiques du Muséum publient aussi / The Museum Science Press also publish:

Adansonia, Geodiversitas, Zoosystema, Anthropozoologica, European Journal of Taxonomy, Naturae, Cryptogamie sous-sections Algologie, Bryologie, Mycologie.

L'Académie des sciences publie aussi / The Académie des sciences also publishes:

Comptes Rendus Mathématique, Comptes Rendus Physique, Comptes Rendus Mécanique, Comptes Rendus Chimie, Comptes Rendus Géoscience, Comptes Rendus Biologies.

Diffusion - Publications scientifiques Muséum national d'Histoire naturelle

CP 41 - 57 rue Cuvier F-75231 Paris cedex 05 (France)

Tél. : 33 (0)1 40794805 / Fax: 33 (0)1 40793840

diff.pub@mnhn.fr / http://sciencepress.mnhn.fr

Académie des sciences, Institut de France, 23 quai de Conti, 75006 Paris.

(C) Publications scientifiques du Muséum national d'Histoire naturelle / (c) Académie des sciences, Paris, 2021

ISSN (imprimé / print): 1631-0683/ ISSN (électronique / electronic): 1777-571X 


\section{The first representative of the trap-jaw ant genus Anochetus Mayr, 1861 in Neogene amber from Sumatra (Hymenoptera: Formicidae)}

Valerie NGÔ-MULLER

UFR Sciences du Vivant, Université de Paris, Sorbonne Paris Cité, F-75013 Paris (France) and Institut de Systématique, Évolution, Biodiversité (ISYEB), UMR 7205, CNRS, MNHN, UPMC, EPHE, Muséum national d'Histoire naturelle, Université des Antilles, Sorbonne Université, 57 rue Cuvier, CP 50, Entomologie, F-75005, Paris (France) valerie.ngo-muller@u-paris.fr (corresponding author)

Romain GARROUSTE

Thomas SCHUBNEL

Institut de Systématique, Évolution, Biodiversité (ISYEB), UMR 7205, CNRS, MNHN, UPMC, EPHE, Muséum national d'Histoire naturelle, Université des Antilles, Sorbonne Université, 57 rue Cuvier, CP 50, Entomologie, F-75005, Paris (France)

Jean-Marc POUILLON 178 rue des Plattières, F-38300 Nivolas Vermelle (France)

Vigo CHRISTOPHERSEN Arne CHRISTOPHERSEN

Starborn Creations, 105 Portal Lane, 86336 Sedona, Arizona (United States)

André NEL Institut de Systématique, Évolution, Biodiversité (ISYEB), UMR 7205, CNRS, MNHN, UPMC, EPHE, Muséum national d'Histoire naturelle, Université des Antilles, Sorbonne Université, 57 rue Cuvier, CP 50, Entomologie, F-75005, Paris (France) 


\begin{tabular}{|c|c|}
\hline \multirow{7}{*}{$\begin{array}{l}\text { KEY WORDS } \\
\text { Insecta, } \\
\text { Hymenoptera, } \\
\text { Formicidae, } \\
\text { Ponerinae, } \\
\text { new species, } \\
\text { umatran amber. }\end{array}$} & ABSTRACT \\
\hline & $\begin{array}{l}\text { The ponerine ant Anochetus miosumatrensis Ngô-Muller, Garrouste } \& \mathrm{Nel} \text {, n. sp. is described from } \\
\text { a fossil alate female preserved in amber of Sumatra which is reputedly of Miocene age. On the basis }\end{array}$ \\
\hline & $\begin{array}{l}\text { of the general morphology, the fossil could be attributed to the extant Sumatran species group risit } \\
\text { Brown, 1978. By comparing with the living environment of the extant species, this ant probably }\end{array}$ \\
\hline & lived in a warm humid forest where it was trapped in dipterocarpacean resin during nuptial flight. \\
\hline & Until now, the known Cenozoic distribution of the genus Anochetus was restricted to the Neotropi- \\
\hline & cal region. Thus $A$. miosumatrensis Ngô-Muller, Garrouste \& Nel, n. sp. brings the first record of the \\
\hline & enus from Indomalaya biogeographic region. \\
\hline & RÉSUMÉ \\
\hline & $\begin{array}{l}\text { La première fourmi du genre Anochetus Mayr, } 1861 \text { de l'ambre néogène de Sumatra (Hymenoptera: } \\
\text { Formicidae). }\end{array}$ \\
\hline & $\begin{array}{l}\text { La fourmi ponérine Anochetus miosumatrensis Ngô-Muller, Garrouste \& Nel, n. sp. est décrite } \\
\text { à partir d'une femelle fossile ailée, conservée dans l'ambre de Sumatra, réputée d'âge Miocène. }\end{array}$ \\
\hline MOTS CLÉS & Sur la base de la morphologie, le fossile pourrait être attribué à l'espèce actuelle du groupe risii \\
\hline $\begin{array}{r}\text { Insectes, } \\
\text { Hymenoptera, }\end{array}$ & fourmi a probablement vécu dans une forêt chaude et humide, où elle a été piégée dans une résine \\
\hline $\begin{array}{l}\text { Formicidae, } \\
\text { Ponerinae, }\end{array}$ & diptérocarpacéenne pendant le vol nuptial. Jusqu'à présent, la distribution cénozoïque connue \\
\hline èce nouvelle, & était restreinte à la zone néotropicale. Ainsi, $A$. miosumatrensis Ngô-Muller, Garrouste \& Nel, \\
\hline
\end{tabular}

\section{INTRODUCTION}

Ponerinae were estimated to originate about 73 million years ago (Mya) in the most recent molecular analysis of ants (Borowiec et al. 2019). But the two putative fossil records from the Turonian (-91 Mya) of South Africa and the Campanian (-72 Mya) of Myanmar suggest an older age (Dlussky et al. 2004; Barden 2017; Zheng et al. 2018). Ponerine ants become more and more abundant through the Cenozoic, being known as fossils in the Nearctic, Palearctic and Australian regions, either as compression fossils or inclusions in amber (Barden 2017).

Trap jaws have evolved independently several times in ants, and are found in the subfamilies Formicinae, Myrmicinae, and Ponerinae (review in Larabee \& Suarez 2014), as well as in the extinct Sphecomyrminae (Perrichot et al. 2016). Within the Ponerinae, the tribe Ponerini consists of 25 genera, among which both the genus Anochetus Mayr, 1861 and its sister group Odontomachus Latreille, 1804 exclusively contain trapjaw ants (Brown 1976, 1978; revised by Larabee et al. 2016).

The genus Anochetus is predominantly intertropical and forest-inhabiting (Brown 1978). In the Indomalaya bioregion where Sumatra belongs, there are 4691 ant species, but only 14 of the 1307 Indonesian species belong to Anochetus. To date, 115 Anochetus species have been described worldwide (Antweb at https://www.antweb.org/, accessed September 2019).

Brown (1978) proposed a phylogeny and a key to the Anochetus species from Asia, Melanesia, and the Pacific region. New species of Anochetus from the Philippine Islands were described recently (Nuril Aida \& Idris 2011; Zettel 2012). The most recent paper on the genus Anochetus is a revision of the extant Chinese species (Chen et al. 2019).
Going back in time, one subfossil is known from the Holocene Madagascan copal, while eight fossil Anochetus species were described from the Miocene Dominican amber (Baroni-Urbani 1980; MacKay 1991; De Andrade 1994; Vankerkhoven et al. 2010; Antweb).

Here we describe the first fossil Anochetus discovered in the reputedly Miocene Sumatran amber. It is an alate queen that was probably trapped in resin during nuptial flight. Larabee et al. (2016) proposed dates for the different Anochetus species groups. Thus the study of this new fossil may help to test the maximum age of this Sumatran amber currently determined on the basis of stratigraphy.

\section{MATERIAL AND METHODS}

The fossil is preserved in a piece of relatively darkened yellow amber, which was carefully ground and polished prior to examination and photography. It is part of a small collection of 53 amber pieces with inclusions bought from a local trader (Starnborn Creations). This material will be deposited by JeanMarc Pouillon in the near future in an official institution. This fossil resin is assigned to the Glessite group (Narudeesombat et al. 2014; Naglik et al. 2018) and was probably produced by trees of the family Dipterocarpaceae, likely close to Shorea Roxb. ex C.F.Gaertn. (1805). Sumatran amber is a byproduct of coal mining, and different ages ranging from Eocene to Pliocene have been recorded for these coal mines (Belkin \& Tewalt 2007; Bak et al. 2016). Previous reports of Sumatran amber, although from different localities, suggested an early Miocene age and a dipterocarp tree source (Durham 1956; Langenheim \& Beck 1965; Brackman et al. 1984; Lambert et al. 1999, 2013). 
The material comes from the South Sumatra Basin, probably from Sinamar, Dharmasraya Regency, West Sumatra, in a mine supposedly Miocene in age (15-25 Mya) (De Smet \& Barber 2005). Many fossils within these amber inclusions are deformed because the amber was probably heated by volcanic activity that occurred in the area during the Miocene (KosmowskaCeranowicz et al. 2017). It is especially the case for this fossil ant, thus the body shape was partially deformed rendering the dimensions weakly indicative.

The fossil was studied and measured using incident and transmitted light with stereo microscopes (Olympus SZX9 and Nikon SMZ 1500). Images were digitally compiled using Zerene Stacker software, and arranged using Adobe Photoshop software. Life Science Identifiers (LSIDs) are used as the globally unique identifier for ZooBank registration entries (Pyle \& Mitchell 2008). The LSID number of the article was generated by us and appears at the beginning of the article.

Morphological terminology follows Brown (1976, 1978) and Zettel (2012), with a modification of head and pronotum measurements. Due to amber deformation, the fossil was laterally compressed, rendering pronotum width not indicative. We thus transformed pronotal index (PI) into $\mathrm{PrH} / \mathrm{HH}$. The following measurements were used for morphological descriptions (Figs $1 ; 2$ ).

ABBREVIATIONS
$\begin{array}{ll}\text { Morphological terminology } \\ \text { CI } & \text { cephalic index; } \\ \text { FWL } & \text { maximum length of forewing; } \\ \text { HH } & \text { head height; } \\ \text { HL } & \text { head length; } \\ \text { HW } & \text { head width; } \\ \text { MdI } & \text { mandibular index; } \\ \text { MdL } & \text { mandible length; } \\ \text { PI } & \text { pronotal index; } \\ \text { PeH } & \text { petiole height; } \\ \text { PeL } & \text { petiole length; } \\ \text { PrH } & \text { pronotum height; } \\ \text { SI } & \text { scape index; } \\ \text { SL } & \text { scape length; } \\ \text { TL } & \text { total length; } \\ \text { WL } & \text { webers length. }\end{array}$

Private collection

coll. JMP Jean-Marc Pouillon, Nivolas-Vermelle.

\section{SYSTEMATIC PALEONTOLOGY}

Class INSECTA Linnaeus, 1758

Order HYMENOPTERA Linnaeus, 1758

Family FORMICIDAE Latreille, 1809

Subfamily Ponerinae Lepeletier de Saint-Fargeau, 1835

Tribe POnERINI Lepeletier de Saint-Fargeau, 1835

Genus Anochetus Mayr, 1861

\section{REMARKS}

According to the key to Asian species of Anochetus (Brown 1978), combined with data in more recent publications (Nuril Aida \& Idris 2011; Zettel 2012; Chen et al. 2019), this fossil Anochetus belongs to the $A$. risii Brown, 1978 group as defined by Brown (1978). A number of Anochetus species of the risii group are present in Java, Malaysia and Philippines. Altogether, the fossil A. miosumatrensis Ngô-Muller, Garrouste \& Nel, n. sp. is closer to Anochetus tua Brown, 1978 than to any other species of risii group. However, a unique combination of characters is observed in this fossil queen ant from the Miocene of Sumatra, allowing to consider it as a new species as described below.

Anochetus miosumatrensis

Ngô-Muller, Garrouste \& Nel, n. sp.

(Figs 1-3)

urn:Isid:zoobank.org:act:DF5A8BCF-55A8-47B9-A730-4B235C993D13

ETYMOLOGY. - Named after the Miocene period and the Sumatra Island.

HOLOTYPE. — Specimen JMP2362 (alate queen), stored in coll. JMP.

LOCUS TYPICUS. — Sinamar, Dharmasraya Regency, West Sumatra, South Sumatra Basin, Miocene.

DiAGNOSIS. - Mandibles very thin in basal part and distinctly broadened at apex; petiolar node much narrow at base; subpetiolar process large with subtriangular ventral margin; deeply U-shaped posterior part of head, rounded anterior margin of gaster from lateral view.

\section{DESCRIPTION}

Measurements and indices

HL $1.25 \mathrm{~mm}$; HW $0.7 \mathrm{~mm}$; HH $0.4 \mathrm{~mm}$; SL $0.8 \mathrm{~mm}$; MdL $1.25 \mathrm{~mm}$; PrH $0.4 \mathrm{~mm}$; FWL $2.7 \mathrm{~mm}$; PeL $0.4 \mathrm{~mm}$; PeH 0.47 mm; WL $1.1 \mathrm{~mm}$; TL $5.0 \mathrm{~mm}$; CI 56; PI 100; MdI 100; SI 114

Body

Dark, fairly preserved, except for missing apices of mandibles destroyed during preparation, dorso-ventral flattening of head, thorax, and propodeum, and splitting of antennae and legs.

\section{Head}

Pyriform, much longer than broad (CI: 56), broadened in the anterior third, widest at the level of eyes, eyes on laterallyproduced ocular prominences (Fig. 1C) with deeply concave ventral margin in ventral view; posterior head margin deeply emarginate medially, forming diverging, strongly pointed posterolateral corners; mandible elongate, adjacent, subporrect, lying nearly parallel at full closure, with dorsal margin edentate, each with at least two teeth directed ventrally in an apical group, dorsal margin without distinct teeth; antenna long and slender, with 12 flagellomeres, hardly visible; scape exceeding posterior corner of head; in lateral view of mesosoma; pronotum apparently sculptured over entire disc, with dorsal outline slightly convex from anterior to posterior; posterior corner of propodeum weakly angulate; petiole higher than long, petiolar node narrowly rounded at apex, with vertical margins; subpetiolar process developed, with subtriangular ventral margin; forewing with a distinct pterostigma; venation as in Figure 2; gaster oval; 

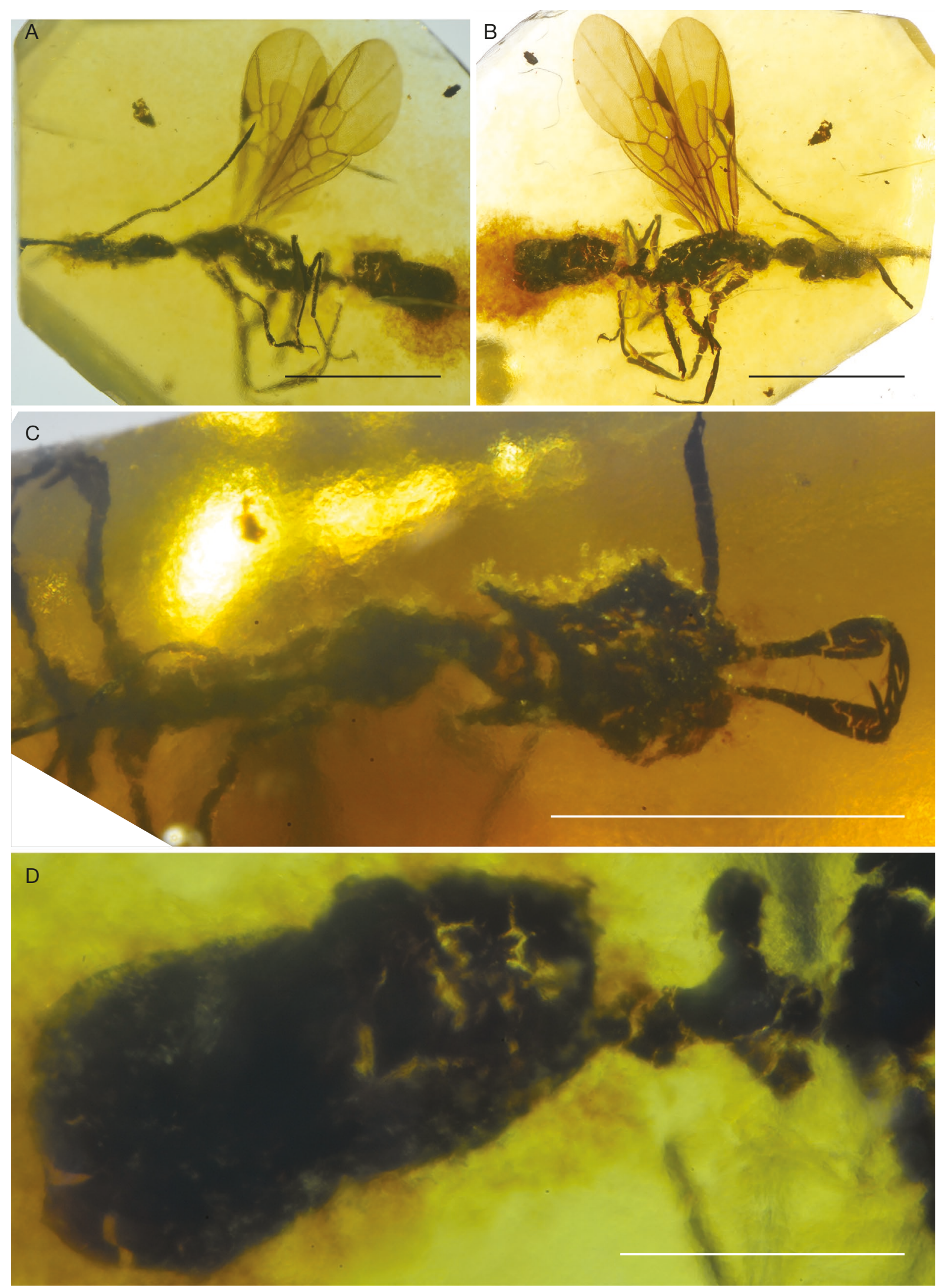

FIG. 1. - Anochetus miosumatrensis Ngô-Muller, Garrouste \& Nel, n. sp., holotype JMP2362: A, habitus in left lateral view; B, habitus in right lateral view; C, head and mesosoma in ventral view; metasoma in lateral view. Scale bars: A, B, 2 mm; C, $1 \mathrm{~mm}$; D, $0.5 \mathrm{~mm}$. 

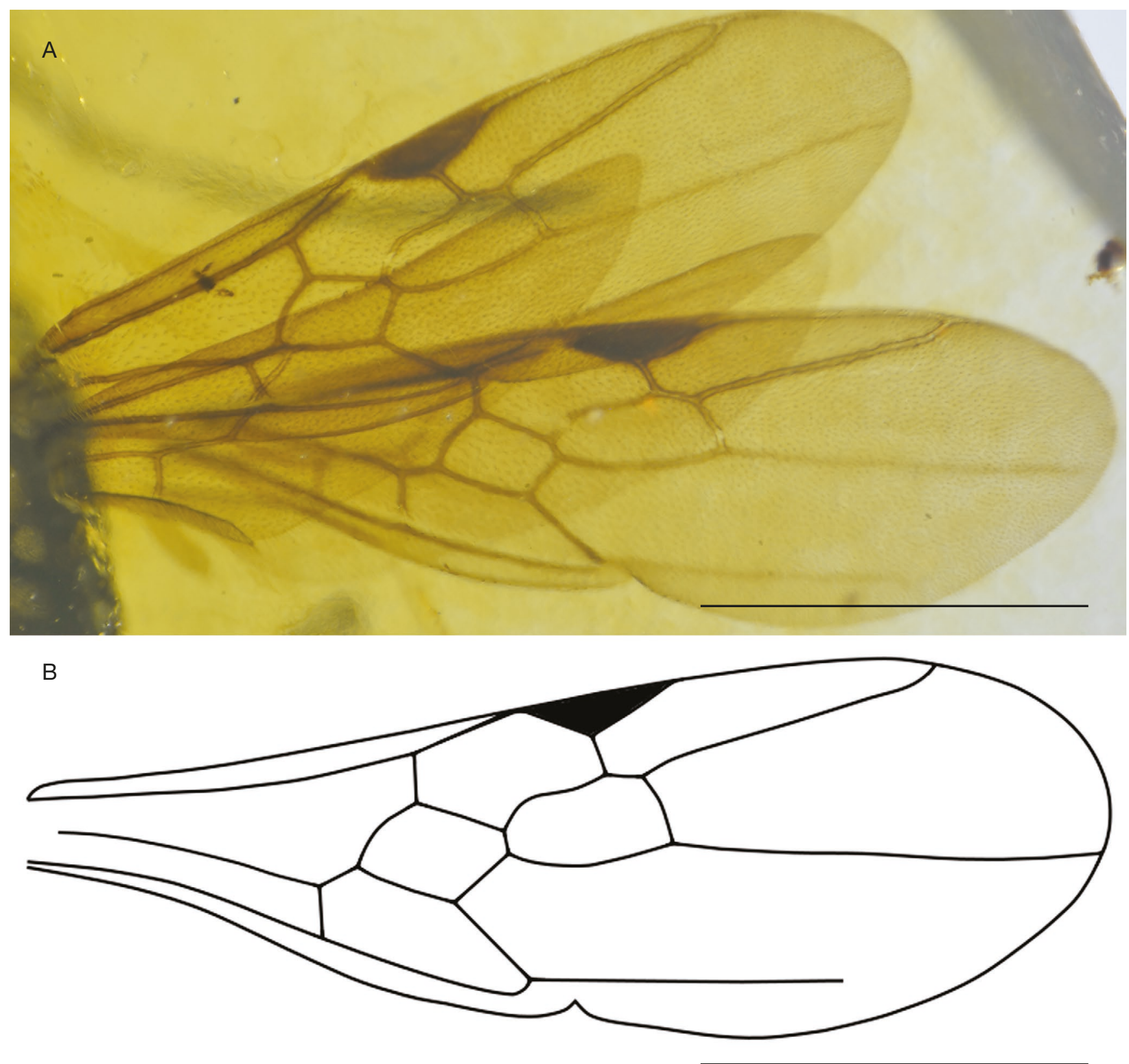

FIG. 2. - Anochetus miosumatrensis Ngô-Muller, Garrouste \& Nel, n. sp., holotype JMP2362: A, fore wings; B, forewing reconstruction. Scale bars: 1 mm.

third abdominal tergum sub-trapezoidal with slightly convex anterior margin and straight posterior margin.

\section{DISCUSSION}

After (Brown 1976, 1978), this fossil belongs to Anochetus rather than to Odontomachus, because of the following characters: pyriform head, broadened in anterior third, with eyes situated at broadest part on laterally-produced ocular prominences, combined with elongate, adjacent, subporrect trap-jaw mandibles lying nearly parallel at full closure, each with three teeth (at least two are visible in our fossil) in an apical group, with apical tooth ventral at apex; nuchal carina forming a broad uninterrupted curve across posterodorsal extremity of head, with median groove absent.

If we follow the key to species of Asia, Melanesia and Pacific regions (internet site Antwiki at http://www.antwiki.org/wiki/ Welcome_to_AntWiki), Anochetus miosumatrensis Ngô-Muller, Garrouste \& Nel, n. sp. would fall near $A$. tua because of the following characters: mesial edge of mandible with two margins up to preapical tooth or angle; dorsal margin edentate; pronotum apparently sculptured over the entire disc; posterior lobes of head very pronounced and acute. The petiolar node narrowly rounded at apex is also shared by $A$. miosumatrensis Ngô-Muller, Garrouste \& Nel, n. sp. and A. tua. The latter is currently recorded from Malaysia and Borneo, but not from Sumatra. Anochetus tua belongs to the risii group of Brown 


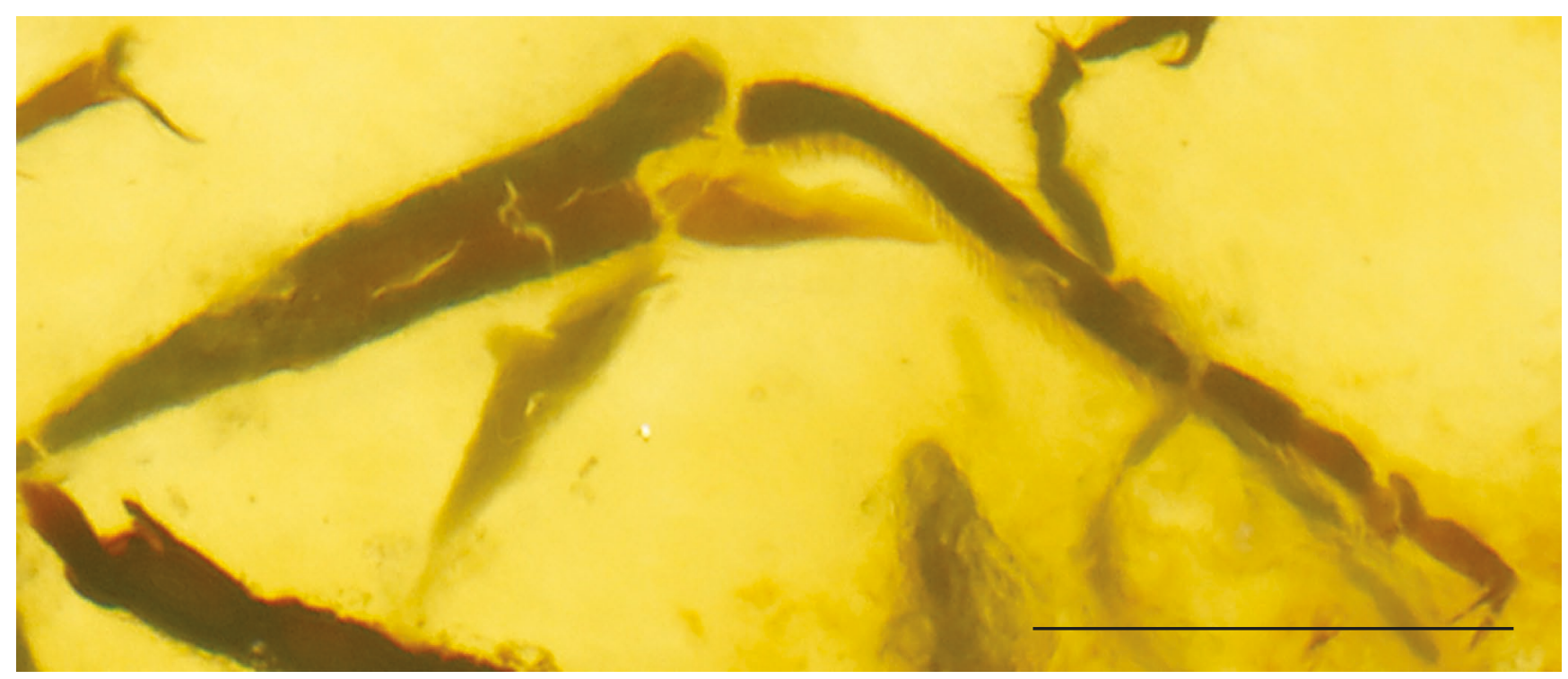

FIG. 3. - Anochetus miosumatrensis Ngô-Muller, Garrouste \& Nel, n. sp., holotype JMP2362. Fore tibia and tarsus. Scale bar: 0.5 mm.

(1978). This author characterized the risii group as follows: mandibles each with distinct dorsal and ventral margins, the upper edentate (except for preapical angle), the lower one with small, serial, spaced teeth, or crenulate, or smooth (crenulate in A. miosumatrensis Ngô-Muller, Garrouste \& Nel, n. sp.); intercalary tooth of mandibular apex arises from well beyond mid-length of ventral apical tooth (not visible in A. miosumatrensis Ngô-Muller, Garrouste $\&$ Nel, n. sp.); preapical angle usually well marked; mesonotal disc with a blunt anterior rim, or none (not visible in A. miosumatrensis Ngô-Muller, Garrouste \& Nel, n. sp.); petiolar node pointed or narrowly rounded at apex (narrowly rounded in A. miosumatrensis NgôMuller, Garrouste $\& \mathrm{Nel}, \mathrm{n}$. sp.). It is reasonable to attribute A. miosumatrensis Ngô-Muller, Garrouste \& Nel, n. sp. to this group of species, which otherwise comprises the species risii, tua, agilis Emery, 1901, brevis Brown, 1978, incultus Brown, 1978, modicus Brown, 1978, strigatellus Brown, 1978, peracer Brown, 1978, and maryatiae (Nuril Aida \& Idris, 2011). This group is centered in SE Asia, and extends to the Philippines and mainland New Guinea. However, only the species agilis, incultus, risii, modicus, strigatellus, and tua are present in Malaysia, near to Sumatra.

Anochetus miosumatrensis Ngô-Muller, Garrouste \& Nel, n. sp. differs from $A$. agilis and $A$. modicus in thinner mandibles in the basal part, and a petiolar node much narrower at base. Anochetus miosumatrensis Ngô-Muller, Garrouste \& Nel, n. sp. differs from $A$. incultus in the deeply U-shaped posterior part of head and a petiolar node much narrower at base. It differs from $A$. risii in the same characters plus the mandibles broadened at apex. Anochetus risii has also a round angle between the proximal and apical parts of the mandible, a subpetiolar process absent, and the anterior margin of gaster rounded (Chen et al. 2019). Anochetus strigatellus has the mandibles very broad at base, an acute petiolar lobe and stronger teeth on mesial part of mandible. Anochetus miosumatrensis Ngô-Muller, Garrouste \& Nel, n. sp. shares with
A. tua a deeply U-shaped posterior part of head, mesonotal disc with a blunt anterior rim, and the petiole thin and narrowly rounded at the apex (petiolar node is often more strongly axially compressed in queen), first segment of gaster large, and separated from second by a distinct constriction. However, A. miosumatrensis Ngô-Muller, Garrouste \& Nel, n. sp. differs from $A$. tua in the mandibles narrow at base but much broader near their apices, and the basal part of the petiolar node much narrower. Anochetus miosumatrensis Ngô-Muller, Garrouste \& Nel, n. sp. also resembles $A$. maryatiae from the Philippines in the shapes of mandibles and of dorsal petiolar lobe, and differs from $A$. maryatiae in the subpetiolar process being larger (Nuril Aida \& Idris 2011).

Extant Anochetus sp. have small nests in soil, in termite nests, under logs, in humus and leaf litter at the bases of large trees, and in rotten wood. A few species are arboreal. They are predators on small arthropods, caught and killed or incapacitated by the ants. A similar biology can be inferred for $A$. miosumatrensis Ngô-Muller, Garrouste \& Nel, n. sp. Larabee et al. (2016) estimated the divergence time between Anochetus and Odontomachus at around $53 \mathrm{Mya}$, during the Lower Eocene, while separation dates for the main subgroups of Anochetus are much more recent, around $40 \mathrm{Mya}$ or less. A. miosumatrensis Ngô-Muller, Garrouste \& Nel, n. sp. belongs to the risii group while the species from the Dominican amber belong to the emarginatus Fabricius, 1804, inermis André, 1889, cato Forel, 1901, and altisquamis Mayr, 1887 groups (see De Andrade 1994). Larabee et al. (2016) estimated the risii group to have emerged during the Lower Miocene, while the cato group would have appeared at the Upper Miocene. The emarginatus group would have emerged during the Oligocene. Thus the current discovery of $A$. miosumatrensis Ngô-Muller, Garrouste \& Nel, n. sp. and its affinities with the risii group supports a Miocene rather than an older age for this Sumatra amber, in accordance with its geological dating. 


\section{Acknowledgements}

We sincerely thank anonymous referees for their helpful remarks on the first and second versions of the paper.

\section{Disclosure statement}

No potential conflict of interest was reported by the authors.

\section{REFERENCES}

BaK M., Natkaniec-Nowak L., Drzewicz P., Czapla D., Ivanina A. V. \& Bogdasarov M. A. 2016. - Ambrosiellalike fungi in fossil resin from Jambi Province in Sumatra Island possible phoretic organisms interacted with invaded insects. 17th Czech-Slovak-Polish Palaeontological Conference, Kraków: 1.

BARDEN P. 2017. - Fossil ants (Hymenoptera: Formicidae): ancient diversity and the rise of modern lineages. Myrmecological News 24: 1-30 (corrected version). https://doi.org/10.25849/myrmecol.news 024:001

BARONI-URBANI C. 1980. - Anochetus corayi n. sp., the first fossil Odontomachini ant. Stuttgarter Beiträge zur Naturkunde (B) $55: 1-6$

Belkin H. E. \& Tewalt S. J. 2007. - Geochemistry of Selected Coal Samples from Sumatra, Kalimantan, Sulawesi, and Papua, Indonesia. United States Department of the Interior, Geological Survey, Open-File Report 2007-1202: 1-34. https://pubs.usgs. gov/of/2007/1202/

Borowiec M. L., Rabeling C., Brady S. G., Fisher B. L., SChultz T. R. \& WARD P. S. 2019. - Compositional heterogeneity and outgroup choice influence the internal phylogeny of the ants. Molecular Phylogenetics and Evolution 134: 111-121. https://doi.org/10.1016/j.ympev.2019.01.024

Brackman W., Spaargaren K., Van Dongen J. P. C. M., CoupeRUS P. A. \& BAKKER F. 1984. - Origin and structure of the fossil resin from an Indonesian Miocene coal. Geochimica et Cosmochimica Acta 48: 2483-2487. https://doi.org/10.1016/00167037(84)90299-0

BROWN W. L. JR. 1976. - Contributions towards a reclassification of the Formicidae. 6. Ponerinae tribe Ponerini subtrib. Odontomachini. Section A. Introduction, Subtribal characters. Genus Odontomachus. Studia Entomologica 19: 67-171. https:// doi.org/10.5281/zenodo. 27000

BROWN W. L. JR. 1978. — Contributions towards a reclassification of the Formicidae. 6. Ponerinae tribe Ponerini subtrib. Odontomachini. Section B. Genus Anochetus and bibliography. Studia Entomologica 20: 549-638. https://doi.org/10.5281/zenodo.27003

Chen Z., YANG Z. \& ZHOU S. 2019. - Review of the ant genus Anochetus Mayr 1861 (Hymenoptera: Formicidae) from China, with revival of the valid status of Anochetus gracilis. Journal of Hymenoptera Research 68: 49-74. https://doi.org/10.3897/ jhr.68.30784

De ANDrade M. L. 1994. - Fossil Odontomachini ants from the Dominican Republic (amber collection Stuttgart: Hymenoptera, Formicidae. 7. Odontomachiti). Stuttgarter Beiträge zur Naturkunde (B) 199: 1-28. https://doi.org/10.5281/zenodo.26365

De Smet M. E. M. \& Barber A. J. 2005. - Chapter 7. Tertiary stratigraphy, in BARBER A. J., CROW M. J. \& MiLSOM J. S. (eds). Sumatra: geology, resources and tectonic evolution. Memoirs of the Geological Society London 31: 86-97. https://doi.org/10.1144/ GSL.MEM.2005.031.01.07

Dlussky G. M., Brothers D. J. \& Rasnitsyn A. P. 2004. The first Late Cretaceous ants (Hymenoptera: Formicidae) from southern Africa, with comments on the origin of the Myrmicinae. Insect Systematics \& Evolution 35: 1-13. https:// antcat.org/references/131125
Durham J. W. 1956. — Insect bearing amber in Indonesia and the Philippine Islands. The Pan-Pacific Entomologist 32: 51-53. https://www.biodiversitylibrary.org/page/56382810

KOSMOWSKA-CERANOWICZ B., SACHANBIŃSKI M. \& ŁYDŻBAKOPCZYŃSKA B. 2017. - Analytical characterization of "Indonesian amber" deposits: evidence of formation from volcanic activity. Baltica 30: 55-60. https://doi.org/10.5200/baltica.2017.30.06

Lambert J. B., Shawl C. E., Johnson S. C. \& Poinar G. O. Jr. 1999. - Fossil resin from Asia. Ancient Biomolecules 3: 29-35.

Lambert J. B., Levy A. J., Santiago-Blay J. \& Wu Y. 2013. Nuclear Magnetic Resonance characterization of Indonesian amber. Life: The Excitement of Biology 1: 136-155. https://doi. org/10.9784/LEB1(3)Lambert.02

LANGENHEIM J. H. \& BECK C. W. 1965. — Infrared spectra as a means of determining botanical sources of amber. Science 149 52-55. https://doi.org/10.1126/science.149.3679.52

LaRABEe F. \& SuAREZ A. 2014. - The evolution and functional morphology of trap-jaw ants (Hymenoptera: Formicidae). Myrmecological News 20: 25-36.

Larabee F. J., Fisher B. L., Schmidt C. A., Matos-Maraví P., Milan JANDA M. \& SuAREZ A. V. 2016. - Molecular phylogenetics and diversification of trap-jaw ants in the genera Anochetus and Odontomachus (Hymenoptera: Formicidae). Molecular Phylogenetics and Evolution 103: 143-154. https://doi.org/10.1016/j. ympev.2016.07.024

MACKAY W. P. 1991. - Anochetus brevidentatus, new species, a second fossil Odontomachiti ant (Hymenoptera). Journal of the New York Entomological Society 99: 138-140. https://doi. org $/ 10.5281$ /zenodo. 25883

Naglik B., Kosmowska-Ceranowicz B., NatKanieC-NowaK L., DrZeWicz P., Dumanska-SŁOWiK M., Matusik J. M., Milovsky R., Stach P. \& SzYszKa A. 2018. - Fossilization history of fossil resin from Jambi Province (Sumatra, Indonesia) based on physico-chemical studies. Minerals 8: 1-14. https://doi. org/10.3390/min 8030095

Narudeesombat N., Ounorn P., Bupparaenoo P., Arne ChrisTOPHERSE A., Pisutha-ARNOND V. \& SutThirat C. 2014. Update on the characteristics of amber from Indonesia. The $4^{\text {th }}$ International Gem and Jewelry Conference: 271-276. https:// hal.sorbonne-universite.fr/hal-02374681/document

NurIL AidA I. N. \& IDRIS A. B. 2011. - Anochetus maryatiae, new species of Ponerinae (Hymenoptera: Formicidae). Sains Malaysiana 40: 301-304.

Perrichot V., Wang Bo \& Engel M. S. 2016. — Extreme morphogenesis and ecological specialization among Cretaceous basal ants. Current Biology 26: 1468-1472. https://doi.org/10.1016/j. cub.2016.03.075

Pyle R. L. \& MiChel E. 2008. — ZooBank: Developing a nomenclatural tool for unifying 250 years of biological information. Zootaxa 1950: 39-50. https://doi.org/10.11646/zootaxa.1950.1.6

VANKERKHOVEN F., HENDERICKX H. \& DEKONINCK W. 2010. Anochetus madagascarensis Forel 1887 found in Madagascan copal (Hymenoptera: Formicidae). Bulletin de la Société Royale Belge d'Entomologie 146: 216-219.

ZETTEL H. 2012. - New trap-jaw ant species of Anochetus MAYR 1861 (Hymenoptera: Formicidae) from the Philippine Islands, a key and notes on other species. Myrmecological News 16: 157-167.

Zheng D., Chang S.-C., Perrichot V., DutTa S., Rudra A., Mu L., Kelly R. S., Li S., Zhang Q., Zhang Q., WONG J., WANG J., Wang H., Fang Y., Zhang H. \& Wang B. 2018. - A Late Cretaceous amber biota from central Myanmar. Nature Communications 9 (3170): 1-6. https://doi.org/10.1038/s41467-018-05650-2

Submitted on 25 March 2019; accepted on 20 December 2019; published on 18 January 2021. 